\title{
Climate-Smart Agriculture: Compost Amendments
}

This fact sheet is the second installment of a four-part climate-smart agriculture series exploring the relationship between carbon farming, soil health, and soil amendments on CA croplands and rangelands. This fact sheet focuses on compost and subsequent fact sheets will address the benefits of biochar and pulverized rock. The series is intended for members of the technical assistance community who advise CA growers on climate-smart agriculture.

\section{What is compost?}

Composting is the managed decomposition of organic materials by microorganisms under high temperatures. The end product, compost, is a soil amendment rich in organic matter and nutrients and is safe to use with respect to both weed propagules and pathogenic organisms. Compost is receiving attention for its soil carbon storage potential as well as its potential role as a replacement for inorganic fertilizers. Compost is recognized by CA Department of Food and Agriculture for its capacity to enhance soil health and sequester carbon in soils, which may help CA meet carbon neutrality targets. Compost is a vital part of nutrient management on organic farms and ranches under USDA's National Organic Program. This fact sheet focuses on properties of compost that reduce waste and are beneficial to producers, making agriculture more sustainable and promoting carbon storage in agricultural soils.

\section{Benefits of compost may include:}

Increase soil organic matter

Increase N, P, \& K

Increase micronutrients

Increase microbial activity

Reduce soilborne disease

Increase water holding capacity

Increase cation exchange capacity

Reduce soil erosion

Reduce soil compaction

Increase carbon sequestration

Increase carbon sequestration

Adapted from Martinez-Blanco, J., Lazcano, C., Christensen, T.H., Munoz, P., Rieradevall, J., Møller, J., \& Boldrin, A. (2013). Compost benefits for agriculture evaluated by life cycle

assessment. A review. Agronomy for sustainable development, 33(4), 721-732.

\section{Diverting organic waste to reduce greenhouse gas emissions}

Compost can be made from a variety of waste materials such as food waste, green waste, and animal manure. Diverting organic waste (food and green waste) from the landfill lowers greenhouse gas emissions.

- Organic waste makes up around 1/3 of California's waste

- When organic waste is diverted from landfills and composted, methane emissions are greatly reduced ${ }^{1}$

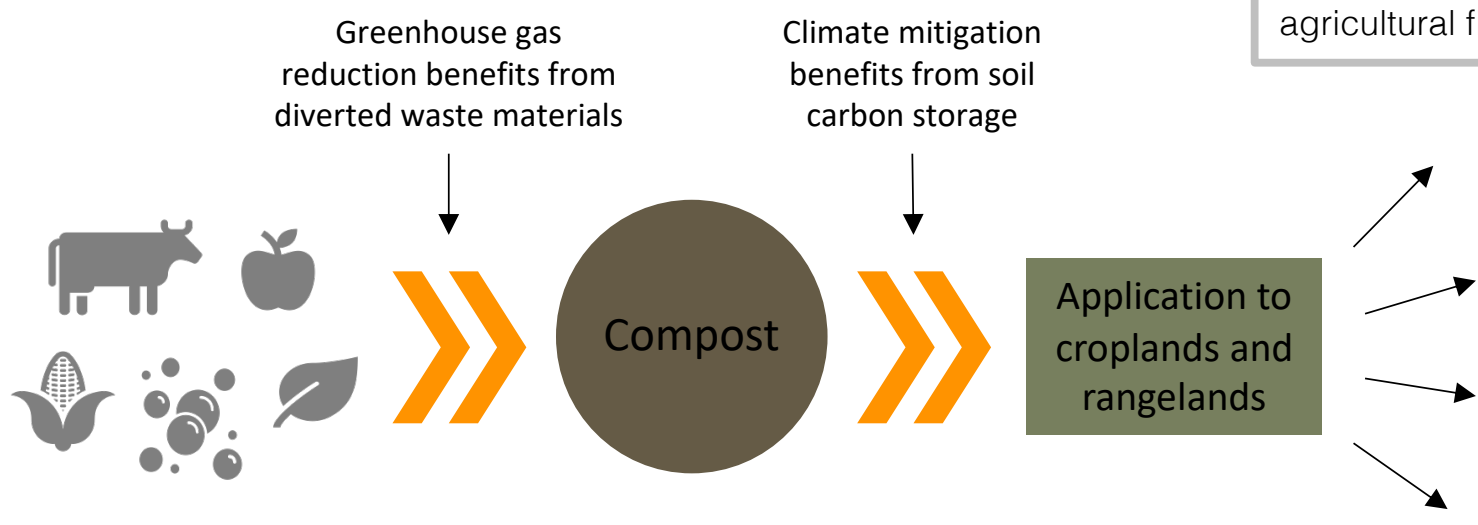

Compost may contribute to making agriculture more sustainable by diverting waste, providing fertility to the soil, and reducing the need for other inputs such as chemical fertilizers and animal feed.

\section{Composting animal waste}

Composting manure waste from dairies and other animal facilities has many benefits, including using manure that may otherwise create negative environmental impacts such as surface water pollution. Composting animal wastes can lower nitrate production and pollution, and lower greenhouse gas emissions. ${ }^{2,3}$ Composting manure properly at high temperatures can kill pathogens and reduce volume and water content, making a product that is lighter and easier to transfer and apply to agricultural fields. ${ }^{4}$

Increased soil organic matter

(SOM) and soil organic carbon (SOC)

Increased crop yield and forage production

Robust soil microbial communities

Enhanced water holding capacity and infiltration, and decreased soil compaction 


\section{Cropland}

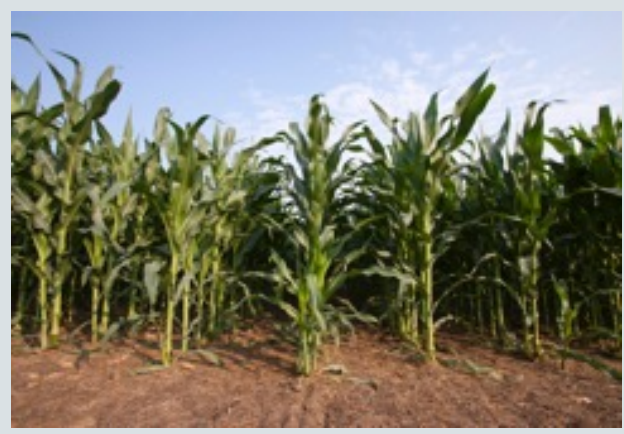

Image: Lynda Richardson, NRCS Photo Library

\section{Rangeland}

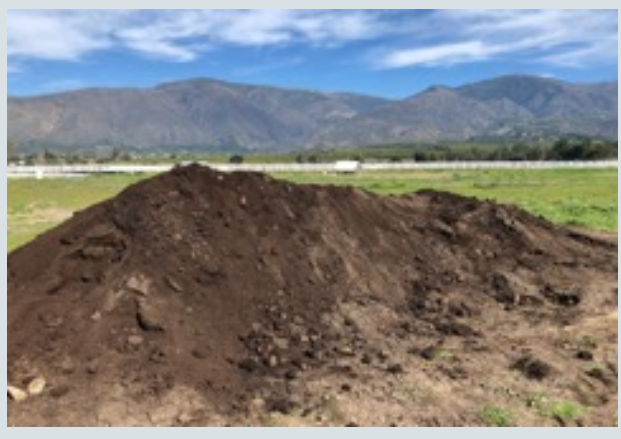

Image: Maya Almaraz, 2019
Applying compost may provide several benefits to growers including increased resilience to climate-related impacts such as drought or heat waves. Compost increases soil organic matter (SOM) which may have benefits for yield, water holding capacity and retention, soil structure, and soil carbon. ${ }^{5}$ A long-term experiment at UC Davis shows compost can drive substantial increases in soil carbon storage. ${ }^{6}$ Compost adds both macro- and micronutrients to the soil and enables reduction of synthetic fertilizer inputs. Additional benefits include suppression of soilborne diseases by microorganisms. ${ }^{7}$ Compost can be applied to croplands annually or more than once a year, prior to each planting. Compost can also be applied to permanent cropping systems like orchards and vineyards and may provide many of the same benefits. ${ }^{8}$

Research suggests application on rangelands can have carbon storage benefits and similar soil health benefits to croplands. ${ }^{9}$ Research shows increased carbon sequestration in soils after only a single application, demonstrating the potential benefits for climate change mitigation. ${ }^{3}$ On rangelands, compost can increase plant productivity and thereby reduce the need for purchased feed. ${ }^{10}$ Additionally, compost may reduce drought risk by increasing water holding capacity, reduce erosion, and decrease soil compaction. ${ }^{9}$ It is advised to use compost on soils with low baseline levels of SOM in order to minimize risk to native plant communities which are better able to compete with invasive species in nutrient-poor environments. As rangeland forage production typically has lower nutrient demand than annual crops, lower nitrogen composts, applied only once every few years, are recommended for rangelands. Barriers to compost use on rangelands include: slopes too steep for mechanical spreading equipment; unique soils, such as serpentines or histosols, and native plant communities that may not benefit from compost application.

\section{Where can growers find more information?}

$>\quad$ UC ANR Solution Center for Nutrient Management, compost here

$>\quad$ CalRecycle, compost and mulch use in agriculture here

$>\quad$ American Carbon Registry, compost additions to grazed lands here

$>\quad$ EPA, sustainable management of food here

$>\quad$ A new NRCS Soil Carbon Amendment conservation practice standard will be released Fall 2020 - see this press release for more information
The Working Lands Innovation Center (WLIC) aims to catalyze negative carbon emissions by deploying soil amendment technologies at multi-acre scales in partnership with California researchers, state agencies, industry, farmers, ranchers, Tribes and smallbusiness development. See their website.

1. Brown, S. (2015). Compost Science \& Utilization, 24(1), 11-19. doi:10.1080/1065657x.2015.1026005

2. Vergara, S. E., et al. (2019). Environmental Research Letters, 14(12), 124027. doi:10.1088/1748-9326/ab5262

3. Silver, W.L., et al. (2018). University of California, Berkeley. California's Fourth Climate Change Assessment, California Natural Resources Agency. Publication number: CCCA4-CNRA-2018-002.

4. Animal Feeding Operations - Uses of Manure. (2020). Retrieved from https://www.epa.gov/npdes/animal-feeding-operations-uses-manure

5. Martínez-Blanco, J., et al. (2013). Agronomy for Sustainable Development, 33(4), 721-732. doi:10.1007/s13593-013-0148-7

6. Tautges, N. E., et al. (2019). Global Change Biology, 25(11), 3753-3766. doi:10.1111/gcb.14762

7. Noble, R., et al. (2005). Biocontrol Science and Technology, 15(1), 3-20. doi:10.1080/09583150400015904

8. Baldi, E., et al. (2018). Science of The Total Environment, 637-638, 918-925. doi:10.1016/j.scitotenv.2018.05.093; Ramos, M. (2017).

Agricultural Water Management, 191, 67-76. doi:10.1016/j.agwat.2017.05.013

9. Ryals, R., et al. (2013). Ecological Applications, 23(1), 46-59. https://doi.org/10.1890/12-0620.1

10. DeLonge, M.S., et al. (2013). Ecosystems, 16, 962-979. https://doi.org/10.1007/s10021-013-9660-5

\section{John Muir nstitute of the Environment}

This fact sheet was developed by the USDA Climate Hub and the Working Lands Innovation Center. Any errors or omissions are the responsibility of the authors and can be directed to the USDA California Climate Hub. The lead author is Emilie Winfield, a graduate student researcher at UC Davis and the USDA CA Climate Hub, with input from Steven Ostoja (USDA CA Climate Hub). Thank you to Jeffrey Creque (Carbon Cycle Institute) and Whendee Silver (UC Berkeley) for serving as reviewers. For fact sheets on other topics related to CA agriculture, please visit https://www.climatehubs.usda.gov/hubs/California. 